\title{
ISLAMIC EDUCATION CONSTRUCTION IN THE PERSPECTIVE OF FALSIFICATION OF KARL R. POPPER
}

\author{
Abd. Rahim Razaq \\ Universitas Muhammadiyah Makasar \\ Jl. Sultan Alaudin No. 259 Makasar, Sulawesi Selatan, Indonesia, 90221 \\ Email:abdrahimrazaq@gmail.com \\ Umiarso* \\ Universitas Muhammadiyah Malang \\ J1. Raya Tlogomas No.246, Kota Malang, Jawa Timur, Indonesia, 65144 \\ *Email corresponding author: umiarso@umm.ac.id
}

Received: 9, 2019. Accepted: 12, 2019 . Published: 12, 2019.

\begin{abstract}
Epistemology as a branch in philosophy has an important position in science including in Islamic education. This research critically examines the epistemological construction of Islamic education through a perspective of falsification which was coined by Karl R. Popper. This research used a qualitative approach to the type of literature study and analyzes data through a productive hermeneutical approach. The conclusion of this research shows that scientific epistemology needs to be designed to understand the theories, concepts, and propositions of the Islamic education system. Scientific epistemology contains the verificative-philosophical logic and intuition-revelation logic (Qur'an and al-Hadith. This epistemology has a rational-critical, empirical, intuitive, and prophetic (illahiyah) dimension and it is called Prophetic Criticism. The implication is that Islamic education will have an integrative view of the profane (physical) and transcendental (metaphysical) side. Islamic education is the logical-superlogical content of subjective-objective thinking, the world of theorysupratheory, and critical argumentation with a rational-intuitive foundation of self and outside selfviews.
\end{abstract}

Keywords: Epistemology, Falsification Popper, Islamic education

\begin{abstract}
ABSTRAK
Epistemologi sebagai salah satu cabang dalam filsafat memiliki kedudukan yang penting dalam ilmu pengetahuan termasuk di dalam pendidikan Islam. Riset ini mengkaji secara kritis konstruksi epistemologi pendidikan Islam melalui perspektif falsifikasi yang dicetuskan Karl R. Popper. Riset ini menggunakan pendekatan kualitatif dengan jenis studi pustaka serta menganalisis data melalui pendekatan bermenutika produktif. Kesimpulan riset ini menyatakan bahwa epistemologi keilmuan yang perlu dirancang untuk memahami teori, konsep, serta proposisi sistem pendidikan Islam adalah epistemologi -atau tata kerja ilmiah-yang memuat logika verifikatif-falsifikatif dan logika intuisi-kewabyuan (al-Qur'an dan al-Hadis). Epistemologi ini memiliki dimensi rasional-kritis, empiris, intuitif, dan profetik (illabiyah) yang penulis diistilabkan Kritisisme-Profetik. Implikasinya, pendidikan Islam akan memiliki pandangan integratif terhadap sisi profan (fisis) dan transendental (metafisis). Ia merupakan isi logis-supralogis pemikiran subjektifobjektif, dunia teori-suprateori, serta argumentasi kritis dengan landasan rasional-intuitif dari pandangan diri sendiri maupun luar diri.
\end{abstract}

Kata Kunci: Epistemologi, Falsifikasi Popper, Pendidikan Islam 


\section{INTRODUCTION}

Epistemology is a branch in philosophy and it has a very important meaning for the building of knowledge (Moser, 2002; Bianca \& Piccari, 2015; Burhanuddin, 2018; Delic, 2017; Gallagher, 2005; Lechte, 2007; Qomar, 2007; Sodiq, 2017; Watloly, 2001). Therefore, in the world of education, epistemology has a strategic position to continue to develop educational concepts and theories (Humaidi, 2013; Rangkuti, 2019) including Islamic education theory (Hanafi, 2011; Rangkuti, 2019; Humaidi, 2013; Sumedi, 2009; Syaifudin, 2013). Moreover, Islamic education continues to be in the midst of a changing society and has an education subject who continues to be (being) and is in the process of forming themselves (Gallagher, 2005). It is normal if epistemology will continue to be used to develop educational theories. In addition to these two things, normatively, Islam also encourages people to think about and examine the dynamics of nature and humanity -this pattern is only possessed by ulu al-albāb (Surah Ali Imran verses 190-191). Therefore, Islam explicitly explains that in developing science, the use rationality-empirical basis for epistemology is a possible way. Although this process consists of the levels of certainty, namely: through cognition, perception, and experience (Nor, 2003).

To develop some concepts, theories, and propositions, Islamic education uses the study of epistemology as its basic framework (Jalaludin, 2011). Islamic education in its epistemological building is not only designed as a humanitarian authority (such as rationalityempirical or intuitive) but also arises from a transcendental normative framework (such as revelation, inspiration, and guidance). These two slices (the humanitarian and normative authority of divinity) do not stand alone but are integrated with an epistemological unity (Arifin, 2014; Hery, 2008; F. Rahman, 1984; Rizal, 2016; Wahyuddin, 2018). Whereas to test the truth of concepts, theories, and the propositions produced, it is done by verifying through inductive logic. Experts try to gather the facts of the field as proof of the truth of the concept, proposition, or hypothesis. Some Islamic education experts explicitly support this concept include Daulay, 2014; Muhaimin, 2015; Muhammad, 1992; or Qomar, 2014. Even the figure of Ibn Taymiyah is a figure who believes in inductive logic-considered the only form of authoritative argument.

The emergence of conclusions about the truth of scientific theory in Islamic education has been objective. This level arises because scientific truth has been empirically proven through a series of experiments. In other words, scientific theories (concepts or propositions) are said to be meaningful, even to the extent that they have achieved scientific truth if they can be verified with sensory (empirical) data. In fact, the building of Islamic education science will be more solid if the truth is a lot of denials of the construction of concepts, theories, propositions, or hypotheses in it. Therefore, the falsification triggered by Karl R. Popper needs to be used as a perspective to test the construction of the truth of Islamic education. This is justified in one of Komarudin's (2014) writings which concluded that the philosophical principle of Karl R. Popper was very appropriate to be applied in various Islamic scientific studies, or research from Mohammad (Dochmie, 2018) which led to the conclusion that the Islamic sciences through the principle of falsification can be verified (the scientific dimension). Even in education, the principle of falsification is able to identify problems effectively, as summarized from the Margison, (2010) study.

The truth of a scientific discipline lies in empirical rationality as evidenced by verification. However, that truth is not a reality as long as the truth is not falsifiable. Therefore, in the context of the truth of the epistemology of Islamic education, the truth parameter does not lie in inductive verification but lies in falsifiability. This is exemplified by Popper (1992) through a statement about Geese having white feathers not the truth as long as gray geese are not found. This pattern or criterion is a demarcation line based on the 
asymmetry between verity and falsifiability. Therefore, universal statements containing propositions or hypotheses cannot be derived from a single statement but can be contradicted by singular revelation (Taryadi, 1991). That is, the construction of the epistemology of Islamic education to find the truth of a theory, propositions or hypotheses is not a "must" use to the principle of verification.

Principle is actually the source of problems in the body of Islamic education itself. The reason is in the principle of verification, according to Popper (1962), a theory will result in positive dimensions, so it is possible to distinguish between empirical and metaphysical knowledge and/or to give limitations to science and pseudoscience. Therefore, there are at least two problems that arise in this domain, namely: first, the verificative principle only leads Islamic education experts to focus on the facts that correspond to their propositions or hypotheses. The verificative principle ignores the facts of anomalies that are contrary to their propositions or hypotheses because they only collect appropriate empirical evidence. Second, the compilation of theories, propositions or hypotheses that exist in Islamic education will be partly considered pseudoscience (metaphysics) because they do not have empirical truth (rational-verification). Therefore, the epistemological construction of Islamic education does not only look at the positivistic-verification side, but the other side also needs to be weighed by the Karl R. Popper falsification approach. Thus, this research focuses on the epistemological construction used to build Islamic education's knowledge. This research brings out into the question: What is the epistemological construction of Islamic education in the philosophical perspective of Karl R. Popper? The basis for finding meaning from the epistemological framework of Islamic education is seen from the philosophical point of view of Karl R. Popper.

\section{METHOD}

This research used a qualitative approach applying library research. Data were collected through library research. The analysis of data applied a productive hermeneutic approach. That is a method for producing new interpretations by interpreting the text (symbol) of philosophical thinking in the context when the researcher reads it through the philosophical perspective of Karl R. Popper.

\section{RESULTS AND DISCUSSION \\ An Overview of Karl R. Popper}

Karl Raimund Popper was born in Vienna on July 28, 1902. He inherited his interest in philosophy from his father, Sigmund Carl Popper. At the age of 16, he left his school "real gymnasium" because he thought that the lessons were not interesting. Then he came to the University of Vienna and in 1922 and he was accepted as a student. For several years he embraced the communism then he decided not to follow it. Popper's rejection of Marxism during his teenage years left a profound mark on his thought. He had at one point joined a socialist association, and for a few months in 1919 considered himself a communist. He did not simply accept an uncritical dogmatism and he became anti-Marxist for a lifetime. His encounter with Marxism was acknowledged as one of the important events in his intellectual development.

In 1919, Popper heard what Einstein was doing and this event dominated his thinking. He once listened to Einstein's lecture in Vienna and was interested in Einstein's theory which could not be sustained if it failed a particular test. He looked for experiments whose compatibility with his predictions did not mean to confirm his theory. Mismatch between theory and experiment will determine whether the theory can be maintained or not. According 
to him, this attitude is different from the dogmatic Marxist attitude which seeks to look for justifications (verification) of its flagship theory.

His most important works in the field of social science-The Poverty of Historicism (1944) and The Open Society and Its Enemies (1945) — were inspired by his reflection on the events of his time and represented, in a sense, a reaction to the prevalent totalitarian ideologies that then dominated Central European politics. His books defended democratic liberalism as a social and political philosophy. They also represented extensive critiques of the philosophical presuppositions underpinning all forms of totalitarianism.

Popper thought that Einstein's theory, as a theory properly grounded in scientific thought and method, was highly "risky", in the sense that it was possible to deduce consequences from it which differed considerably. The nature of such theories made it impossible for any criticism or experiment-even in principle-to show them to be false. When Popper later tackled the problem of demarcation in the philosophy of science, this conclusion led him to posit that the strength of a scientific theory lies in its both being susceptible to falsification, and not actually being falsified by criticism made of it. He considered that if a theory cannot, in principle, be falsified by criticism, it is not a scientific theory.

\section{Philosophy of Karl R. Popper: Falsification}

In general, the philosophy of Karl R. Popper is more patterned as a counter to a positivistic ideology that tends to develop inductive thinking methods. In the philosophy circle of science, he is considered to exist against various thoughts or ideologies that break all knowledge through verification. He considered the inductive method unable to distinguish between science and pseudo-science; between empirical science and non-empirical science (Berkson \& Wettersten, 2003). He even considered that the method could not distinguish the system between empirical science and logic, and mathematics as metaphysics (Popper, 1992). These thoughts are the starting point of the philosophy of science of Karl R. Popper. However, he asserted that the opposing thoughts were logical thinking; as he stated that he was very rationalist in criticizing the opinions of others and he was willing to accept criticism and learn from the criticism (Popper, 1983).

Karl R. Popper thought was not free from criticism. Thomas S. Kuhn describe the criticism to Popper. He stated, Popper had twisted the facts by parsing the emergence of empirical science through hypothetical paths and new falsifications were arranged. This effort was commonly carried out as a general effort in empirical science, after which Popper put forward a number of examples in the history of science to be used as evidence of defending and defending his assumptions (Kuhn, 1993). This criticism indicates, Popper's view was able to influence the basic framework of validation of the truth of science. The opinion of Thomas S. Kuhn provides a point of clarity on the basis of philosophy developed by Karl R. Popper who tried to develop science through criticism based on empirical facts. Therefore, the empirical criticism of Karl R. Popper appears not based on assumptions that were born in a vacuum, but it arises from the dialectic between the inductive-verification method and falsification.

The dividing line (between verificative-inductive and falsification) is what is said to be a demarcation criterion. The verifiable principle explicitly and strongly rejects knowledge that is not based on real facts, including rejection of metaphysics because it does not have a real empirical source of facts and is finally claimed to be meaningless. Through the demarcation criterion, Karl R. Popper could sort and distinguish between science and pseudo-science; between real science and fake science. Because he considers inductivism to put the position of the principle of science into static. There are conditions that need to be fulfilled by "something" considered to be science, according to inductivity, namely: observable, 
repeatable, measurable, testable, and predictable. And it turns out that stability only breeds chaos and stagnation in discovering new knowledge, including in the knowledge of Islamic education.

Based on this description, the philosophical thinking of Karl R. Popper's knowledge is indeed very interesting to use in the construction of knowledge of Islamic education. Because in Islamic education not only worldly orientation arises but also there is a religious orientation. It is these two orientations that need to be weighed using a falsification framework to see nonempirical-verification scientific facts (i.e. eschatological metaphysics). This thought arises not only based on the material framework of Islamic education knowledge but also arises from the material thinking of Karl R. Popper himself. The development of Karl R. Popper's philosophy can be divided globally into two periods, namely: the period of crisis rationalism (methodological) and the metaphysical period (Schipp, 1974). The methodological period includes the fields of induction, demarcation, and falsification; while the metaphysical period speaks of the world (Taryadi, 1991).

In the aspect of methodology, falsification serves as a form of strong criticism of neopositivistic position itself and as a solution or alternative. Therefore, falsification offers ideas in which there are criticisms to test errors in theory or science. The more theory or science survives from criticism or from an effort to uncover its mistakes, the more corroborative (reinforced) the existence of the theory will be. In the view of philosophy, there is no theory or science that has definitive or final truths, only propositions or hypotheses (temporary guesses). That is, the principle of falsification confirms that the power of a theory, proposition, or hypothesis is not determined by the level of validity/truth of the theory, proposition, or hypothesis, but it is determined by the power to prove its error (proof of error) (Popper, 1962). From this, the application of the deductive method for testing the reliability of a theory is very possible, therefore science will continue to develop.

\section{Epistemology of Islamic Education}

Epistemology is a branch of philosophy that breaks down critically about science (Bagir, 2017; Maksudin, 2016; Ravertz, 2014; Tafsir, 2010). Epistemology is considered as a philosophy of knowledge because it enables to discuss the construction of knowledge starting from its origin, its boundaries, the nature, methods, and validity of that knowledge. It can be said as philosophical science that is specifically geared to get the essence of knowledge. When it comes to discuss the epistemology, one should understand the epistemological material object, namely knowledge; while the formal object is the essence of knowledge itself. The discussion starts from the meaning of knowledge, the process of growth and development of knowledge, kinds of knowledge, and methods in knowledge (Asy'ari, 2001). Therefore, the methodology is used to compile knowledge in accordance with the standards of truth, theories, propositions, or hypotheses.

In this context, the discussion of the epistemology of Islamic education is more oriented towards approaches that can build knowledge or theory of Islamic education. The epistemology approach is the most possible entity to develop Islamic education knowledge in terms of theoretical and applicative. Scholars who examine epistemology in various disciplines have been emerged like Bagir, 2017; Effendi, 2013; Mujahidin, 2013; or Yazdi, 1992. In Islamic education, the study of epistemology has also been written by several figures, namely Abdullah (in Mulkhan \& et.al., 1998); Ahmad \& Lubis, 2017; Syaifudin, 2013; Widiyanto, 2017). This indicates that epistemology has a strategic role in developing science, particularly Islamic education. The development of science is also increasingly confirming the existence of epistemology as a part that must not be abandoned. Naturally, if the philosophical study of Islamic education is more often parsed on the epistemological dimension than ontological and axiological dimensions. Therefore, this study at this level -read axiological- explore an area that 
is rarely investigated in Islamic religious education (Umiarso \& Makhful, 2018) and Islamic education and philosophical Sufism (Umiarso, 2019).

Qomar (2014) formulates five kinds of epistemological approaches to building Islamic education that guides to the attainment of piety or human closeness with God. The five epistemological approaches include the rational method (manhaj 'aqli), the intuitive method (manbaj íanqi), the method of criticism (manhaj naqdi), the comparative method (manbaj muqärani), and the dialogical method (manhaj jadali) (Qomar, 2014). Suyudi (2005); Umiarso \& Asnawan (2017) divides three types of approaches, namely; empirical methods, logical methods, and intuitive methods or revelations. These epistemological approaches are essentially functioning to foster and increase the awareness of the subject of education about knowledge. In essence, the subject of Islamic education in developing theories or knowledge of Islamic education emphasizes not only the results but also the process of how to obtain them. Therefore, epistemology provides a comprehensive, detailed and intact understanding.

Islamic education cannot be separated from the framework of the methodology -read epistemology to build a true knowledge. Sources, objects, and methods should be understood and examined in order to be able to obtain and build theories in Islamic education. Although between Islamic education and conventional education has a different pattern, especially at the source and method. The source of Islamic education is the verses of qawliyyah (the Qur'an and the Hadith) and qawniyyah (the universe). While the method for obtaining the truth continues to integrate between profane values -humanitarian authority- with the normative value of divinity. In constructing the truth of knowledge, as in Arifin's thought, it still follows scientific thinking based on Islamic values Ghofur (2016). So, the epistemology that is built does not let go of profanity values as an arena for the struggle of Islamic education theory. This is in line with the development of al-Farabi's educational philosophy pyramid, namely the internalization of naturalism, nativism, and empiricism.

The main characteristics of the epistemology of Islamic education are strongly tied to the normative value of verse qawliyyah, and place it as the ultimate paradigm. In this realm, the epistemology of Islamic education is integrated and framed with these prophetic values, even though theories, propositions, or hypotheses arise through a rational-empirical or positivisticverification pattern. With a dialectical-consultative or confrontational-contradictory pattern, Islamic education continuously integrates empirical-rationality (as a Hellenistic basis) with doctrinaire-normative revelations (as the basis of Semitic). With this understanding, the Qur'an and the Hadith are able to give birth to the construction of knowledge of Islamic education that is able to understand reality (social-humanities) the way the Qur'an and the Hadith are able to understand the reality. Knowledge of Islamic education through integrative epistemology is expected to be able to educate and enlighten human civilization.

Epistemology which are discussed with integration based on processes involving logical implications is built by removing dichotomous paradigms. In fact, it also fosters knowledge that is submitted to prophetic ethics amr ma'rüf, nabi munkar, and tawhid; this epistemology which is said in one of the research is able to bring up a generation of moslems who are righteous in religion as well as science and technology (Yusuf, 2015). However, most Islamic education experts tend to carry out a positivistic critical-procedural analysis. Logic, hypothesis, and verification are terms that cannot be taken away in analyzing Islamic education knowledge. As if the corrective parameters of the truth of knowledge can only be proven through these procedures, namely inductivity mindset. It is this mindset that encourages empirical observation and experience metamorphosed into evidence and parameters of knowledge objectivity. In fact, withdrawing singular statements into general needs to be tested using a falsification framework (Berkson \& Wettersten, 2003). Including knowledge of Islamic 
education cannot be balanced without using a framework of falsification in order to know the level of truth.

\section{Islamic Education Perspective of Falsification}

Epistemology in Islamic education is needed as a medium to realize the goals that are aspired. In terms of epistemology, according to Widiawati's (2019) Islamic education is expected to reflect the process of forming students who are able to apply their knowledge into their attitudes and actions. Indeed, conceptually, the epistemology of Islamic education has comprehensive characteristics, foundations, and sources, so it is very different from the epistemology of Western education which tends to be partial. Western education prioritizes critical, empirical, and theoretical dimensions, while Islamic education adds one dimension, namely the illahiyah dimension. Therefore, the final orientation of the epistemology of Islamic education is the degree of devotion and the human approach to God (Matin \& Sahed, 2017; Siswanto, 2011) or the benefit of humans in the world and the hereafter. These four dimensions certainly exist in Islamic education, which Sumedi (2007) termed the wisdom criticism.

Islamic education is designed not only to focus on the development of worldly potential -material or physics- but also to embrace aspects of end -immaterial or metaphysics. Based on the ontology framework, Islamic education recognizes being in two domains, namely physics and metaphysics. While on the side of axiology it does not emphasize the realization of pragmatic worldliness but afterlife too. Likewise, the epistemological aspect, the construction of knowledge of Islamic education depends on the power of ratio and empirical or empirical rationality and depends its truth on two normative forces, namely the Qur'an and the Hadith (Sunna). Clearly through this framework, Islamic education can not only be proven through rational-empirical processes, but also at the same time there is an intuitive-metaphysical proof. Therefore, Hanafi (2011) stated that because between science and con-science is a unity, then when developing and exploring concepts of theories and practices it does not stop at the fact but it also needs to be in the fact behind the fact; so there needs to be a definition of metaphysical meanings in each physical proposition.

In a positivistic view, what is stated as a science is a concept, theory, or proposition that can be proven empirically, because positivistic views only consider "ontos" which can be observed positively, namely sensory. In Islamic education, "ontos" is not as reality, but it is a sign of the existence of ultimate reality (God). Islamic education treats "ontos" integratively -it does not separate between physical and metaphysical dimensions; between material and immaterial. However, this does not necessarily make Islamic education enter and lock itself in the view of esotericism and only holds strongly the mystical-sufistic intuition epistemology and subject-essential evaporation. Islamic education still holds strong the urgency of rationalempirical perceptions which guarantees an objectification of objectivism and universalism as its epistemological basis. In the epistemology of Islamic education there are two types of knowledge, namely Kasbi and Ladduni. However, Kasbi science appears to remain based on the positivistic-verification basis.

In Kasbi's science, the chaos of scientific work procedures determines the validity of the truth that is built and the epistemological emphasis is very thick on positivistic. Therefore, Kasbi science does not come at the truth of objective substance which is integrative "ontos" and only reaches the degree of validity of epistemology by using a manipulative-benefit approach. In fact at this time, Kasbi's science designed in Islamic education is the result of theories, propositions, or hypotheses that have been verified through inductive-empirical logic. In fact, the scientific anatomy that composes Islamic education cannot always be proven using that logic, as about the dimensions of aqeedah -the concept of divinity, heaven and hell, angels, or jinn- which cannot be materially -empirically verified. That is, in this realm it cannot 
be proven through inductive inference as in science. Thus, the anatomy of Islamic education cannot be fully verified through particular inductive proofs. Even so, when it cannot be proven it does not mean that Islamic education cannot be regarded as science; there is the highest fact behind the facts. As it has been done by a researcher when examining the facts of diversity and godliness behind the reality of "nista", namely the reality of 'Ayam Kampus'/sex workers (Rijal \& Umiarso, 2018); like other writings that see explicit feuds and implicit integration between sharia law entities and Sufism (Rijal \& Umiarso, 2017).

In terms of positivistic-verification, the truth of Islamic education material-fasting, will not be proven through the rational-empirical dimension. Therefore, Islamic education cannot be said as a science, but it can be said as a deceit science or false science; although it was able to bring the subject of Islamic education to the highest reality that is the divine reality -humans who transform themselves into "God" (Rijal \& Umiarso, 2018). It cannot be denied that Islamic education through inductive verification can be said not as a scientific discipline categorized as pure science with particular, materialistic, and rational-empirical characteristics. Because it is not able to be proven rational-empirically which demands particular materialistic proof, or objectivity has been attempted in the general direction. In this framework, the line of demarcation between science and pseudo-science -falsification- which Popper triggered becomes very relevant so that we can distinguish both of them.

As a science, of course, falsification cannot be separated from the effort to test the construction of concepts, theories, or propositions in Islamic education. It means that testing the truth through systemic and massive denials is needed to strengthen Islamic education as a science, framework or education system. It is clear that Islamic education will be considered legitimate as a science if it has been placed on a rational asymmetric line between variability and falsifiability. On the other hand, it needs to be verified by inductive logic, and also needs to be falsified through deductive logic that can deny the construction of the concepts, theories, or propositions itself. The function of falsification is able to sharpen the implementation of Islamic education. Clearly, falsification does not mean as a systemic and structured effort to reject overall concepts, theories, or propositions in Islamic education.

The construction of Islamic education is a scientific discipline, then the truth is relative insofar as there have not been found anomalies that influences it. Islamic education in this area is only a temporary assumption (hypothesis) that is not final and very open to criticism or even replaced by other educational systems. In this context, the doctrine of Islamic education about the greatness of the behavior of the prophet Muhammad (knotted in four characteristics, namely tabligh, fatänah, amānah, and șiddīa). This great personality should be sought "records" -especially the four traits- to test the truth of these concepts, theories, or hypotheses; and more "no records" are found, more the truth is. This effort by Popper is termed the thesis of refutability that is, a concept, theory, or proposition (hypothesis) if there is a space or gap that allows criticism and denial. Obviously, to test the truth of Islamic education it is necessary to put inductive rationalization as an entry point and to test the objectivity, it is necessary through deductive rationalization. In this area, critical efforts through proof of "right" or "wrong" become the basis of the demarcation of science and the pseudo-science (Popper, 1962), included in the Islamic education system. This domain is what Popper says as a critical phase.

The effort can actually be done by using the epistemological-methodical trilogy of Islamic education, namely bayāni, burbāni, and irfäni. The burhani method (empirical-rationality) is designed to look for loopholes in "notes" of concepts, theories, or propositions that arise from the results of hermeneutical ijtihad (bayani) toward normative texts (the Qur'an and the Hadith). The Qur'an itself in the QS. Āli Imrān [3]: 190-191 has suggested that always think of the signs that exist in the universe through rationality to usher in the entity of faith-Tawhid- 
human; this is called in term ulü al-albāb. Through this procedure, Islamic education -as well as the Qur'an and the Hadith- increasingly affirmed by the existence of truth in the realm of humanity, because it has exceeded the phase of "error" that cannot be realized. Whereas irfan $\overline{1}$ (intuition) confirms the results of the falsification subjectively to arrive at enlightening knowledge; in other words, discursive knowledge needs to be integrated with the knowledge of intuition -the values of spirituality, e.d- so that concepts, theories, or propositions can contribute to human life. This can be seen from the research findings of the author, the kiai's leadership effective in developing pesantren educational institutions, including culture in Islamic boarding schools on the basis of spiritual values -or Islamic values (Umiarso, 2018).

People tend to view the dimension of intuition which is closely related to the entity of metaphysics as an unscientific fact. The objective scientific truth states that the final claim is a lie and it is criticized by Karl R. Popper, Thomas S. Kuhn, Richard Rorty, or Paul Feyerabend (Syamsuri, 2013). Islamic education in this field needs to establish itself as an educational system that cannot be denied and functioned by the benefits of the subject of education. Therefore, it affirmed itself in front of scientific skeptics through various forms of rejection, or even with a test of proof of the error. For example, the relevance of Islamic education values in millennial society with the conclusion "through internalizing the values of Islamic education, society $\mathrm{X}$ has a strong character". This conclusion is an empirical fact which can be proven by disablement or errors through tracking $\mathrm{X}$ community members who have weak characters. If in reality there is no community member with a weak character, then the conclusion is considered wrong. Through proof of this error, Islamic education does not stand on an ignorance assumption or on the basis of mere conviction, but it stands firmly on the foundation of proof of truth through pre-verification verificative-inductive and continued deductive-falsification.

People today are still not accustomed to using the pattern of falsification as an alternation of scientific work procedures for Islamic education. They only recognize a concept, theory, or proposition, if there is something that strengthens, confirms, and justifies its existence; and even they thought, knowledge was confined in the midst of facts that he could not overcome. Though logical positivism indivisivism will not be able to load all the material and dynamics of Islamic education. One of the unique features of Islamic education, fosters educational theories from creative imaginations that emerge from socio-historical wombs and normative texts (the Qur'an and the Hadith). Testing its theory not only confirms, but also finds the validity of educational theory -this is what Popper, (2002) said as an epistemology of open society. It is clear if the scientific theory of Islamic education emerges based on findings or allegations that appear bold to be eliminated if it is contrary to empirical reality. This is what has been epistemologically said by Karl R. Popper in the Philosophy of Science (Mace, 1957). These two thoughts can be distinguished as shown in the following table 1.

Table 1. Though Empirical and Karl R. Popper Logic

\begin{tabular}{lll}
\hline Framework & \multicolumn{1}{c}{ Empirical Logic } & \multicolumn{1}{c}{ Karl R. Popper Logic } \\
\hline Theory & $\begin{array}{l}\text { Require verification through } \\
\text { rationalism-empiric (inductive) }\end{array}$ & $\begin{array}{l}\text { Require falsification through deductive } \\
\text { approach }\end{array}$ \\
\cline { 2 - 3 } $\begin{array}{l}\text { Islamic } \\
\text { education) }\end{array}$ & $\begin{array}{l}\text { Free from the reality of metaphysical } \\
\text { theology (meaningless) }\end{array}$ & $\begin{array}{l}\text { Opened from the reality of metaphysical } \\
\text { theology (meaningful) or heuristic. }\end{array}$ \\
\hline
\end{tabular}

To be precise, it can be said that in the construction of knowledge of Islamic education it cannot be acknowledged without a revelation or otherwise cannot be exposed without empirical rationality. In this section, it is clear that Islamic education cannot be separated from 
the divine (transcendental) dimension; so the science of metaphysics (such as about the Book, the Angels, the Prophet, especially Allah) is the basis of the theory of Islamic education. However, we need to recognize that Islamic education in Greek influence began from the thought system and the substantial analysis of ideas which tend to be intuitive in terms of understanding; Fauzan \& Fata (2018) research states that the classical Islamic tradition of the majority comes from Greece, especially Hellenism; or Roy's (2004) work which revealed that Aristotle's logic inspired the basic framework of qiyäs in ușul al fiqh which was initiated by the Imam of Shafi'i. Thus, the metaphysics of Islamic education is not seen as a pseudo science (pseudo science); precisely metaphysics is shown as something universal, objective and truth is untestable -cannot be proven- (Fuller, 2006; Latif, 2016; Muhadjir, 1998; Wattimena, 2008); and refutable.

Moreover, as Popper said, sains itself has become appear from the idea of metaphysical which examined by empirical realities (Walker, 2019). Therefore, Islamic education can be appeared as a slices of physical reality and universal objective metaphysics. It a common if Islamic education has become an inseparable science wth metaphysical realities, because of these two reasons (empirical-physics and metaphysics) which stands on ontological unity. In this context, researcher agreed with Popper (1992) effort in deleted "the barriers which separate science from metaphysical speculation". In the fact of Islamic education, science appears from the basic of transcendental unity ideas (kawniyyah and qawliyyah verses). The cultivation of Islamic education as a science clearly not a partialistic theme which separate the metaphysics; or regard the methaphysics as an non-scientific realities, because it is not emphirical and rational (condition from positivism ontological science). So, factually, the truth of Islamic education will appears from deductive saintific framework; Therefore, Popper, (1992) is not believes on the truth of science quo status which based from logical inductive.

Islamic education construction is pressing on integrated religion knowledge or include rational-empirical knowledge (Islamic science and the humanities). Actually, these aspects were an absolute righteousness from Popper's science perspective; that is science which not separate science that does not separate verifiable reality (physical) and "only meaningful" (metaphysical). The implication is, although in Islamic education there is a reality that is included in non-empirical and non-rational theory, it does not mean that Islamic education is not scientific (as science). In Popper (1992) language, "no matter how many instances of white swans we may have observed, it does not justify the conclusion that all swans are white".

The emergence of science -read the science of Islamic education- from the womb of revelation or metaphysics is a form of absoluteness. Popper himself strongly believes in the construction of science that emerges from the dimension of metaphysics, but with an emphasis on mindfulness; in Surat Âli Imrān verse 7 is said to be ulu al-albäb -that is, people who only use their minds will be able to take lessons from the verses of qawliyyah (religion) and kawniyyah (science). In line with this, Hidayatullah's (2019) research is said to be the dynamics of relations between science and religion with a form of conflict, independent, conversational, or compatible relational. Even the emergence of science -read the science of Islamic education- from the womb of revelation or metaphysics is a form of absoluteness. Popper himself strongly believes in the construction of science that emerges from the dimension of metaphysics, but with an emphasis on mindfulness; in Surat Âli Imrān verse 7 is said to be $u \bar{u}$ ulu al-albāb -that is, people who only use their minds will be able to take lessons from the verses of qawliyyah (religion) and kawniyyah (science). This sweeping in Hidayatullah's research is said to be the dynamics of relations between science and religion with a form of conflict, independent, conversational, or compatible relations; which has been realized in the applicative form of Islamic religious higher education institutions by M. Amin Abdullah or Imam Suprayogo; or on institutional governance (Irawan, 2014; Arsyad, 2006). There are also 
those who propose an integration mode -between science and religion- in the curriculum in Muslim societies (Thobani, 2007).

Therefore, Islamic education needs to be parsed from the physical ontological framework to metaphysics. Because of this dimension opens meaning to be seen, so that the physical reality (the fact behind the fact) is a metaphysical normative locus on every construction of the theory of Islamic education. The theory of Islamic education does not have to be built from the fact of materialistic-empirical reality -but reality in this context must be falsifiable (Popper, 1992), but also from a metaphysical-intuitive framework. The implication of this attitude, Islamic education philosophy (Filsafat Pendidikan Islam) will emerge as a critical reflection on the construction of theories, concepts, or propositions; and as a dissection of mixing psychological and epistemological problems in Islamic education. Likewise in Islamic education (Ilmu Pendidikan Islam), the theories that arise based on the critical aspects of rationality (reasoning) as an alternative solution to educational problems can be tested through empirical experience while remaining in the normative anchor of the Qur'an and the Hadith. It is not an exaggeration if the two courses will be more meaningful to build a non-dichotomic Islamic education system that unites between science and non-science through a prophetic-based line of demarcation.

\section{Prophetic Criticism: Breaking the Progressive Islamic Education}

Although the concept of falsification developed by Karl R. Popper was able to be a counterweight to the outbreak of the logic of empiricism (positivistic), but this concept tends to perceive the same between the humanities social sciences with natural sciences. The scientific work that is the basis of the thought of the concept of falsification is an objective and rational framework; like positivistic logic. Therefore, this method of scientific work is not fully applicable in the context of Islamic education theories. There are several underlying reasons, including; First, Islamic education theory, concepts, or propositions are not always objective to say as science. One example, Islamic ritual doctrines such as prayer, fasting, or hajj which have axiological subjective nuances in each "subject". Finally, the values in it accumulate towards absolute objective truths; this is actually acknowledged by Popper (1992) through the statement "only in our subjective experience, in our subjective faith, can we be" absolutely certain". And secondly, the doctrinal framework that exists in Islamic education does not all have a scientific rational dimension. Islamic education tends to contain irrational dimensions if it is included in the standards of science, as prayers have "upside down" and relatively irrational movements; or Hajj which has certain rituals that are also irrational.

These characteristics show that Islamic education is a complete set of educational theories. Therefore, scientific epistemological thinking that needs to be designed is the framework of the education system that is able to contain the logic-verification logic, as well as the intuition-revelation logic (the Qur'an and the Hadith). So the epistemology is one that has a rational-critical, empirical, intuitive, and prophetic (illahiyyah) dimension; the author is termed Critical-Prophetic. This framework provides a wide space for optimizing the role of ratios and senses and intuition to critically analyze the dynamics of humanity, experience, and prophetic texts. On the one hand, the prophetic dimension also directs educational theories integrated with religious values, so that they always give birth to the rhythms of humanity's benefit in the world and the hereafter.

Based on this framework, ratios, senses and intuition are better understood as revelations -transcendental dimensions- and the universe -profanistic dimensions- for the life of the subject of education. The implication, between revelation and the universe will be more meaningful and functional for Islamic education to construct theories, concepts or propositions in itself. Islamic education will not emerge from the womb of mere revelation which releases the profanistic side as an anchor or the imperative mode of prophetic value; 
but it emerged and stood as the vanguard of humanization, liberation, and transcendence in the midst of society. The manifestation of these values in Islamic education can take the form of a humanist (M. Rahman, 2013; Subaidi, 2016), pluralist (Nuryatno, 2011, 2013), and egalitarian Islamic education paradigm -gender-based (Solichin, 2006), and scientific integration (Abdullah, 2014). Therefore, Islamic education needs to have a critical-analytical attitude towards empirical reality through a framework of guided verifications -reading on prophetic values (ie humanist, liberative, and transcendent values) which are encapsulated in QS. Âli Imrān [3]: 110. Thus, the workflow of prophetic criticism will schematically appear as shown in Figure 1.

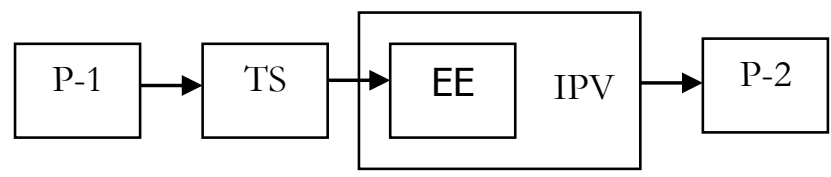

Figure 1: Workflow of Prophetic Criticism

Indeed, the workflow is simply not different from the falsification workflow developed by Karl R. Popper. The workflow starts from P-1 which is the initial problem that raises the Solution Tentation (TS), namely theory, concept, or proposition proposed as a trial framework. In this domain there is an effort to Error Elemination (EE) that evaluates the theory, concept, or proposition with the aim of analyzing critically, finding "records" and discarding them. This effort is a form of test "error" theory, concept, or proposition, so that he is able to bring up P-2 (new theory) due to the existence of a critical evaluation of the tentative solution to the initial problem (Popper, 1962). The difference lies in the Error Elimination (EE) which needs to be refined through Integration of Prophetic Value (IPV) efforts. So, theories, concepts, or propositions are not only sought for "errors" or "errors" to be eliminated but also unite them with the spirit of prophetic ethics. This value can be realized as a reinforcer, inspirational source, or even become an entity that is also tested the level of "truth" following the theory. On the other hand, this value can be realized in the form of axiological spirit that guides and directs theories, concepts, or propositions to have a definite purpose, namely for the benefit of humanity. The implication is that the notion of Islamism will not be strengthened, as research has stated that it is currently expanding in several Islamic Religious Colleges (PTKI: Perguruan Tinggi Keagamaan Islam) (Wildan, 2019).

Clearly, what is said to be the theory of Islamic education in this context is a "construction of paradigmatic thinking" which is tested for its application to empirical reality and needs to be assessed as the result of its suitability. Therefore, the theories of Islamic education originating from the Qur'an and the Hadith are not necessarily in absolute positions. The results of the interpretations of the texts of the Qur'an and the Hadith are in a relative position -non-Islamic reading- which needs to be tested for its validity through a falsification test. If the results of this test show there are "records", then the theory can be said to "need improvement" or not valid. Conversely, if the theory test does not show there is a "record", then it reinforces itself as a theory. Due to its tentative nature, it can be said that theory is actually a form of effort to solve certain problems which are always faced with critical analysis for corrected construction with the aim of finding "records". This domain also explains that the normative texts of revelation (the Qur'an and the Hadith) remain in the absolute dimension and are illabiyyah, while the results of the interpretation of the text are relative and non-illabiyah.

Similarly, metaphysics that tends to be intuitive-subjective in Islamic education needs to be placed into objective knowledge. And intuition in one of the researches is concluded to have very strong relevance to Islamic education, especially if viewed from the aspect of the 
curriculum managed by Islamic education institutions such as madrasas (Lubis, 2018). Therefore, as critical of Irawan's (2014) research, intuition is one of the essential parts of the source of knowledge, although it is subjective. By encouraging intuition to be an objective construct, intuition can be rationally argued to be faced with critical analysis. That is, the theory that emerges from the womb of intuition remains in a framework that can be tested, not a theory building that only pushes on subjective intuition.

Clearly, intuition -subjectivity- can be seen as a subjective theory -seeing knowledge as a disposition (special belief) that is related to other belief entities (Popper, 1992). In contrast, the objectivity of the theory is based on intersubjective testability, so that scientific theory cannot be absolutely justified and can only be tested for its validity. Therefore, the concept of objectivity of Islamic education theory is intersubjective testability that is generalized as the idea of critical rational control which is balanced with critical discussion. Here everyone can criticize, because it is to form scientific objectivity. Thus, to realize this objectivity does not lie in trust but at the critical choice to find a good theory.

At that level, Karl R. Popper proposed the idea of alternation about the world of objective knowledge (world three) to enrich the picture of the world resulting in argumentative and critical imaginative theories. The most important fact in this context is that there is a demarcation line that distinguishes asymmetrically between science and pseudoscience, so it is clearly an area that can be tested with a metaphysical dimension -which cannot be refuted. It's a common thing, if the world of three contains an attitude of rejection of monism which implies dualistic thinking that distinguishes between body-souls. Islamic education with the basis of prophetic criticism has an integrative non-partialistic view of the material and immaterial dimensions; or between the profane (physical) and transcendental (metaphysical). If Karl R. Popper views the third world as an objective world with the anatomy of logical contents of the process of subjective thought, world theory, argumentation and criticism seen from and by himself, prophetic criticism is a logical-supra logical content of subjective-objective thinking, the world of supra theory, critical argumentation with a rationalintuitive foundation from one's own view and from outside oneself.

\section{CONCLUSION}

Islamic education is viewed from the falsification perspective by Karl R. Popper has a very complex segment, caused by extensive ontological, epistemological, and a wide axiological coverage. Although the thought of Popper's scholarly work tends to equate between the theories, concepts, or propositions of the social sciences-humanities with the natural sciences, epistemologically Islamic education is able to be acknowledged like natural sciences. In fact, Islamic education also transcends the scientific workings of the natural sciences, the cause between logical-rational and irrational, physical and metaphysical dimensions, or profane and transcendental cannot be separated into some parts. This is what guides the existence of a comprehensive epistemological study to unravel the construction of Islamic education theory, concepts, or propositions so that the objectivity of educational theory is not as objective as scientific which was criticized by Karl R. Popper, Thomas S. Kuhn, Richard Rorty, or Paul Feyerabend. Therefore, in studying Islamic education, a scientific work system that covers all aspects which in this context is called prophetic criticism is needed.

\section{BIBLIOGRAPHY}

Abdullah, M. A. (2014). Religion, Science and Culture: An Integrated, Interconnected Paradigm of Science. al-Jami'ah: Journal of Islamic Studies, 52(1), 175-203.

Ahmad, S. F., \& Lubis, M. A. (2017). Islam Hadhari dalam Pendidikan Pembangunan Modal Insan di Mayasia: Suatu Analisa Epistemologi, in 7 (1) 2015. Jurnal Hadhari, 7(1), 1-18. 
Arifin, Z. (2014). Pendidikan Islam dalam Perspektif Filsafat Ilmu. Ta'dib: Journal of Islamic education, 19(1), 123-142.

Arsyad, A. (2006). Universitas Islam: Integrasi dan Interkoneksitas Sains dan Ilmu Agama Menuju Peradaban Islam Universal. Tsaqafah: Jurnal Ilmu Pengetabuan \& Kebudayaan Islam, 2(2), 159-183.

Asy'ari, M. (2001). Filsafat Islam: Sunnah Nabi dalam Berfikir. LEFSi.

Bagir, H. (2017). Epistemologi Tasawuf: Sebuah Pengantar. Mizan.

Berkson, W., \& Wettersten, J. (2003). Psikologi Belajar dan Filsafat Ilmu Karl Popper, Translater.: Ali Noer Zaman. Qalam.

Bianca, M. L., \& Piccari (Edit.), P. (2015). Epistemology of Ordinary Knowledge. Cambridge Scholars Publishing.

Burhanuddin, N. (2018). Filsafat Ilmu. Kencana.

Daulay, H. P. (2014). Pendidikean Islam dalam Perspektif Filsafat. Kencana.

Delic, Z. (Edit.). (2017). Epistemology and Transformation of Knowledge in Global Age. InTech.

Dochmie, M. R. (2018). Keilmiahan Ilmu-Ilmu Islam Ditinjau dari Prinsip Falsifikasi Karl Popper. Integration-Interconnection Islam and Sains Conference Proceeding (1)), 145-150.

Effendi, L. M. (2013). Pertautan Epistemologi Filsafat dan Tasawuf: Telaah Sistem Pemikiran Abdul Halim Mahmud. Ulumuna: Jurnal Studi KeIslaman, 17(1), 153-190.

Fauzan, P. I., \& Fata, A. K. (2018). Hellenism Islam: The Influence Greek in Islamic Scientific Tradition. Episteme: Jurnal Pengembangan Ilmu Keislaman, 13(2), 407-432.

Fuller, S. (2006). Kubn V s Popper: The Struggle for the Soul of Science. Icon Books.

Gallagher, K. T. (2005). Epistemologi: Filsafat Pengetahuan, Penya: P. Hardono Hadi. Kanisius.

Ghofur, A. (2016). Konstruksi Epistemologi Pendidikan Islam: Studi atas Pemikiran Kependidikan Prof. H. M. Arifin, M.Ed. Potensia: Jurnal Kependidikan Islam, 2(2), 239-254. http://dx.doi.org/10.24014/potensia.v2i2.2577

Hanafi, I. (2011). Basis Epistemologi dalam Pendidikan Islam. Jurnal Pendidikan Islam, 1(1), 19_ 30. https://doi.org/10.14421/jpi.2011.11.19-30

Hery, M. (2008). Epistemologi Pendidikan Islam: Melacak Metodologi Pengetahuan Perguruan Tinggi Islam Klasik. Insania: Jurnal Pemikiran Alternatif Pendidikan, 13(3), 453-473.

Hidayatullah, S. (2019). Agama dan Sains: Sebuah Kajian tentang Relasi dan Metodologi. Jurnal Filsafat, 29(1), 102-133.

Humaidi. (2013). Epistemologi Kurikulum Pendidikan Sains. Jurnal Pendidikan Islam, 2(2), 263 284. https://doi.org/10.14421/jpi.2013.22.263-284

Irawan, B. (2014). Intuisi sebagai Sumber Pengetahuan: Tinjauan Terhadap Pandangan Filosof Islam. Jurnal Theologia, 25(1), 159-188. http://dx.doi.org/10.21580/teo.2014.25.1.342

Jalaludin. (2011). Filsafat Pendidikan Islam: Telaab Sejarah dan Pemikirannya. Kalam Mulia.

Komarudin. (2014). Falsifikasi Karl Popper dan Kemungkinan Penerapannya dalam Keilmuan Islam. at-Taqaddum: Jurnal Peningkeatan Mutu Keilmuan dan Kependidikan Islam, 6(2), 444465.

Kuhn, T. S. (1993). The Structure of Scientific Revolution, Peterj.: Tjun Surjaman. Remaja Rosadakarya.

Latif, M. (2016). Orientasi ke Arah Pemahaman Filsafat Ilmu. Kencana.

Lechte, J. (2007). 50 Filsuf Kontemporer: Dari Strukturalisme sampai Postmodernitas, Translate.: A. Gunawan Admiranto. Kanisius.

Lubis, Z. (2018). Intuisi Sebagai Sumber Pengetahuan dan Relevansinya Terbadap Pendidikan Islam 'Abd al-Wabhab al-Sya'rani, (Unpublished Dissertation). Universitas Islam Negeri Sumatera Utara.

Mace, C. A. (1957). British Philosophy in The Mid-Century. Allen and Unwin. 
Maksudin. (2016). Metodologi Pengembangan Berpikir Integratif Pendekatan Dialektik, Yogyakarta: Pustaka Pelajar, 2016. Pustaka Pelajar.

Margison, E. J. H. (2010). Scientific Paradigms and Falsification: Kuhn, Popper, and Problems in Education Research. Educational Policy, 24(5), 815-831. https://doi.org/doi.org/10.1177/0895904809339166

Matin, A. B. S., \& Sahed, N. (2017). Tuhan dalam Perspektif Filsafat Pendidikan Islam. elTarbawi: Jumal Pendidikan Islam, 10(1), 1-16. https://doi.org/10.20885/tarbawi.vol10.iss1.art1

Moser, P. K. (Edit.). (2002). The Oxford Handbook of Epistemology. Oxford University Press.

Muhadjir, N. (1998). Filsafat Ilmu: Telaab Sistematis Fungsional Komparatif, Yogyakarta: 1998. Rake Sarasin.

Muhaimin. (2015). Manajemen Pendidikan: Aplikasinya dalam Penyusunan Rencana Pengembangan Sekolah/Madrasah. Kencana.

Muhammad, S. al-Naquib al-Attas. (1992). Konsep Pendidikan dalam Islam: Suatu Rangka Pikir Pembinaan Filsafat Pendidikan Islam, Peterj.: Haidar Baqir. Mizan.

Mujahidin, A. (2013). Epistemologi Islam: Kedudukan Wahyu sebagai Sumber Ilmu. Ulumuna: Jurnal Studi Keislaman, 17(1), 41-64. https://doi.org/10.20414/ujis.v17i1.171

Nor, W. M. W. D. (2003). Filsafat dan Praktik Pendidikan Islam Syed M. Naquib al-Attas, Translater.: Hamid Fahmy, et.al. Mizan.

Nuryatno, M. A. (2011). Islamic education in a Pluralistic Society. al-Jami ab: Journal of Islamic Studies, 49(2), 411-431.

Nuryatno, M. A. (2013). Religious Education and the Challenge of Pluralism in Indonesia. Jurnal Pendidikan Islam, 28(1), 140-155.

Popper, K. R. (1962). Conjectures and Refutation: The Growth of Scientific Knowledge. Basic Book.

Popper, K. R. (1983). Realism and The Aim of Science: From the Postscript to the Logic of Scientific Discovery. Rowman and Littlefield.

Popper, K. R. (1992). The Logic of Scientific Discovery. Routledge.

Qomar, M. (2007). Epistemologi Pendidikan Islam: Dari Metode Rasional bingga Metode Kritik. Erlangga.

Qomar, M. (2014). Menggagas Pendidikan Islam. Remaja Rosadakarya.

Rahman, F. (1984). Islam \& Modernity: Transformation of an Intellectual Tradition. The University of Chicago Press.

Rahman, M. (2013). Guru Humanis dalam Pendidikan Islam. Jurnal Pendidikan Islam, 28(1), 91 106.

Rangkuti, F. R. (2019). Implementasi Metode Tajribi, Burhani, Bayani, dan Irfani dalam Studi Filsafat Pendidikan Islam. al-Muaddib: Jurnal Ilmu-Ilmu Sosial \& Keislaman, 4(1), 41-54. https://doi.org/10.31604/muaddib.v1i1.787

Ravertz, J. R. (2014). Filsafat Ilmu: Sejarah \& Ruang Lingkup Bahasan, Translater: Saut Pasaribu. Pustaka Pelajar.

Rijal, S., \& Umiarso. (2017). Syari'ah dan Tasawuf: Pergulatan Integratif dalam Mencapai Tuhan. Jurnal Ushuluddin, 25(2), 124-136.

Rijal, S., \& Umiarso. (2018). Sex Workers Religiosity and Faith in God: Case Study on "Ayam Kampus" in East Java, Indonesia. Jurnal Kalam, 12(2), 257-282.

Rizal, A. S. (2016). Ilmu sebagai Substansi Esensial dalam Epistemologi Pendidikan Islam. Ta'lim: Jurnal Pendidikan Agama Islam, 14(1), 1-17.

Roy, M. (2004). Ushul Fiqih Madzhab Aristoteles: Pelacakan Logika Aristoteles dalam Qiyas Ushul Fiqih. Safiria Insania Press.

Schipp, P. A. (Edit.). (1974). The Philosophy of Karl Popper. The Open Court Publishing. 
Siswanto. (2011). Epistemologi Pendidikan Islam. Cendekia: Jurnal Kependidikan dan Kemasyarakatan, 9(1), 1-11.

Sodiq, A. (2017). Epistemologi Islam: Argumen al-Ghazali atas Superioritas Ilmu Ma'rifat. Kencana.

Solichin, M. M. (2006). Pendidikan Agama Islam Berbasis Kesetaraan Gender. Tadris: Jurnal Pendidikan Islam, 1(1), 51-60.

Subaidi. (2016). Konsep Pendidikan Islam dengan Paradigma Humanis, in 10 (1) 2016. Nadwa: Jurnal Pendidikan Islam, 10(1), 26-49.

Sumedi. (2007). Ibnu Taymiyyah (1262-1328) dan Karl Raimund Popper (1902-1994): Analisis Perbandingan Epistemologi dan Implikasinya pada Pendidikan Islam. Program Pascasarjana UIN Sunan Kalijaga.

Sumedi. (2009). Ke Arah Epistemologi Pendidikan Islam Humanis. Jurnal Kependidikan Islam, $4(1), 1-34$.

Suyudi, M. (2005). Pendidikan dalam Perspektif al-Qur'an: Integrasi Epistemologi Bayani, Burhani, dan Irfani. Mikraj.

Syaifudin, R. (2013). Epistemologi Pendidikan Islam dalam Kacamata al-Ghazali dan Fazlur Rahman. Episteme: Jurnal Pengembangan Ilmu Keislaman, 8(2), 323-346.

Syamsuri. (2013). Doktrin Objektifisme Ilmu Pengetahuan Modern. Refleksi: Jurnal Kajian Agama dan Filsafat, 13(4), 417-442.

Tafsir, A. (2010). Filsafat Ilmu: Mengurai Ontologi, Epistemologi, dan Aksiologi Pengetahuan. Remaja Rosdakarya.

Taryadi, A. (1991). Epistemologi Pemecahan Masalab Menurut Karl R. Popper. Gramedia.

Thobani, S. (2007). The Dilemma of Islam as School Knowledge in Muslim Education. Asia Pacific Journal of Education, 27(1), 11-25.

Umiarso. (2018). Kepemimpinan Transformasional Profetik dalam Mengembangkan Pesantren di Kabupaten Jember. Akademika: Jurnal Pemikiran Islam, 23(1), 87-106.

Umiarso. (2019). Human Transformation into the "God": Study of Critic-Elaborative Axiology of Islamic education with Philosophical Sufism. Edukasi: Jurnal Penelitian Agama dan Keagamaan, 17(1), 1-13.

Umiarso, \& Asnawan. (2017). Kapita Selekta Pendidikan Islam: Isu-Isu Kontemporer Pendidikan Islam dalam Bingkai Keindonesiaan. Kencana.

Umiarso, \& Makhful. (2018). Puasa dan Pendidikan Agama Islam dalam Membangun Manusia Penaka "Tuhan": Tinjauan Kritis terhadap Sisi Epistemologik dan Aksiologik (Pembelajaran) Pendidikan Agama Islam. Jurnal Pendidikan Islam, 12(1), 129-154.

Wahyuddin. (2018). Sumber-Sumber Pendidikan Islam: Penalaran, Pengalaman, Intuisi, Ilham dan Wahyu. Jurnal Inspiratif Pendidikan, 7(1), 133-146.

Walker, C. (2019). Karl Jaspers and Karl Popper: The Shared Legacy. History of Psychiatry, 30(2), 172-188. https://doi.org/10.1177/0957154X19826473

Watloly, A. (2001). Tanggung Jawab Pengetabuan: Mempertimbangkan Epistemologi Secara Kultural. Kanisius.

Wattimena, R. A. A. (2008). Filsafat dan Sains: Sebuab Pengantar. Grasindo.

Widiawati, N. (2019). Reformulation of The Islamic education Philosophy: A Study of the Epistemological Thought of al-Farabi. al-Afkar: Journal for Islamic Studies, 3(1), 48-63.

Widiyanto, A. (2017). Rekontekstualisasi Pemikiran Sayyed Hossein Nasr tentang Bangunan Ilmu Pengetahuan dan Pendidikan Islam. Islamica: Jurnal Studi KeIslaman, 11(2), 420-448.

Wildan, M., et. al. (2019). Menanam Benih di Ladang Tandus: Potret Sistem Produksi Guru Agama Islam di Indonesia. CISForm UIN Sunan Kalijaga.

Yazdi, M. H. (1992). Ilmu Hudhuri: Prinsip-Prinsip Epistemologi dalam Filsafat Islam. Mizan.

Yusuf, M. Y. (2015). Pesantren Sains: Epistemology of Islamic Science in Teaching System. W alisongo: Jurnal Penelitian Sosial Keagamaan, 23(2), 283-310. 